\title{
SOCIABILIDADE, CULTURA E MEMÓRIA: relatos de moradores de uma localidade litorânea da Ilha de Santa Catarina ${ }^{1}$
}

Tereza Mara Franzoni ${ }^{2}$

Palavras-chave: Sociabilidade; Cultura; Memória; Ilha de Santa Catarina

RESUMO: O trabalho procura fazer uma reflexão sobre a percepção de moradores tradicionais do litoral sul da Ilha de Santa Catarina sobre as transformações sócio culturais ocorridas nos últimos anos em sua localidade a partir do estudo das formas de sociabilidade, em especial aquelas que envolvem as formas associativas e que, na localidade, estão diretamente relacionadas ao planejamento do uso e ocupação do solo.

A pesquisa foi desenvolvida a partir de relatos de vida coletados no segundo semestre de 2005 e início de 2006 (Franzoni, 2005), envolvendo 12 moradores. O procedimento adotado foi: Identificação da lógica interna de cada relato; Identificação dos pontos comuns e divergentes entre os relatos; Identificação das principais categorias nativas e seus significados.

Entre os moradores entrevistados, a imagem do passado é marcada pela quantidade de terras disponíveis. Esta se contrapõe à impressão da falta de terras atual. Para muitos tudo está ocupado, ou, como, dizem "está tudo cercado". A visão de um território livre, sem cercas e de circulação livre, está ligada a memória de um Campeche agrícola, e remete diretamente para as experiências vividas na infância e na adolescência ${ }^{3}$.

Através dos depoimentos, foi possível identificar a participação de meus entrevistados em muitas das atividades que resultaram na elaboração do Plano Diretor Comunitário $^{4}$. A necessidade de terrenos livres, de caminhos de acesso a praia, de áreas de lazer para as crianças, de conter o crescimento populacional, de espaços de festa e de sociabilidades múltiplas, de espaços para feiras e brincadeiras, de espaços artísticos, de

\footnotetext{
${ }^{1}$ Projeto de pesquisa de mesmo nome CEART/UDESC.

${ }^{2}$ Coordenadora da pesquisa, Departamento de Artes Cênicas do Centro de Artes da Universidade do Estado de Santa Catarina

${ }^{3}$ Sobre a memória ilhoa ligada a agricultura ver Lacerda (2003).

${ }^{4}$ Sobre o processo de elaboração do Plano Diretor Comunitário ver Franzoni (2005) e Vigânigo (2004).

DAPesquisa, Florianópolis, v.2, n.4, p. 353-354, 2007.
} 
áreas verdes de acesso livre, aparecem tanto nos depoimentos quanto nas demandas do Plano Comunitário5.

Os motivos que os levaram, ao envolvimento com as questões de planejamento urbano, apontavam, via de regra, para relações de parentesco e amizade, principalmente entre aqueles que moravam no Campeche há algum tempo. Mas envolviam também sua determinação em relação as imagens e desejos que tinham e que tem em relação a este lugar. Seus vínculos, com as organizações comunitárias locais também envolviam, relações de amizade e parentesco, além das motivações e escolhas políticas no campo da negociação dos usos do espaço vivido.

Por fim cabe ressaltar a centralidade do processo de elaboração do Plano Comunitário em relação a sociabilidade ${ }^{6}$ local e, a possibilidade de, através dele, refletir sobre esta sociabilidade, tanto enquanto objeto de estudo, como, e principalmente, enquanto motivador e provocador de reflexão entre os próprios moradores da localidade. Estabelecendo um diálogo entre passado e futuro, entre espaço e memória, entre o tradicional e o novo.

\section{BIBLIOGRAFIA}

FRANZONI, Tereza Mara. "Estrangeiros" e "nativos" - sociabilidade e identificação na Ilha de Santa Catarina [apresentado no GT 02 - Fronteiras Urbanas e circulação de sentidos, na VI Reunión de Antropologia del Mercosur]. Montevidéu, 2005.

LACERDA, Eugênio P. 2003. O Atlântico Açoriano: Uma antropologia dos contextos globais e locais da açorianidade (Tese) Programa de pós graduação em Antropologia Social. Florianópolis, UFSC - Departamento de Antropologia Social. Florianópolis.

SIMMEL, Georg. Sobre a sociedade e a cultura (parte 1). In: SOUZA, Jessé e ÖELZE, Berthold. Simmel e a modernidade. Brasília: Editora Universidade de Brasília, 2005. 2a ed.

VIGÂNIGO, Eliane Rotta. Desenvolvimento local e empowerment no Campeche.

[Monografia] Florianópolis: CCE/UFSC, 2004.

WAIZBORT, Leopoldo. As aventuras de Georg Simmel. São Paulo: Ed 34, 2006. 2a ed. www.campeche.org.br/plano/intro_plano.htm acesso em 08/12/2006.

\footnotetext{
$\overline{5}$ Para acesso ao Plano Diretor Comunitário consultar www.campeche.org.br/plano/intro_plano.htm

${ }^{6}$ Sobre o conceito de socialização ver Simmel (2005) e Waizbort (2006).
}

DAPesquisa, Florianópolis, v.2, n.4, p. 353-354, 2007. 